\title{
Floral biology and pollination of carpet weeds, Glinus lotoides L. and Glinus oppositifolius (L.) Aug. DC. (Molluginaceae)
}

Maddala Sulakshana ${ }^{1}$ \& Aluri Jacob Solomon Raju ${ }^{2}$

1 Department of Botany, Andhra University, Visakhapatnam 530 003, India.

2 Department of Environmental Sciences, Andhra University, Visakhapatnam 530 003, India.

\section{Correspondence}

AJS. Raju

E-mail: solomonraju@gmail.com

Received: 5 January 2018

Accepted: 21 September 2018

Published on-line: 28 November 2018

\section{Resumen}

Biología floral y polinización de las malas hierbas Glinus lotoides $L$. y Glinus oppositifolius (L.) Aug. DC. (Molluginaceae)

Glinus lotoides y G. oppositifolius son hierbas rastreras, esparcidas, anuales. En ambas, las flores son muy pequeñas, actinomorfas, bisexuales, protandradas, herkogamosas y facultativamente autógamas. Ambas especies exhiben antesis sincrónica y flores masivas para atraer a los polinizadores. Las abejas, hormigas, mariposas y trips polinizan las flores. La hercogamia excluye la autogamia espontánea, pero el evento de cierre de la flor facilita esta autogamia. En ambas especies, el fruto es una cápsula con semillas escrotiformes con estrofiolo; anemocoria, ombrohidrocoria e hidrocoria son funcionales. Las semillas germinan inmediatamente si el suelo tiene humedad. Las especies Glinus con fotosíntesis C3, autogamia facultativa y polifilia son capaces de crecer en hábitats secos y húmedos.

Palabras clave: Autogamia facultativa, Polinización por insectos, Anemocoria, Ombrohidrocoria, Hidrocoria.

\begin{abstract}
Glinus lotoides and G. oppositifolius are prostrate, spreading, annual herbs. In both, the flowers are very small, actinomorphic, bisexual, protandrous, herkogamous and facultatively autogamous. Both species exhibit synchronous anthesis and display flowers en masse to attract pollinators. Bees, ants, butterflies and thrips pollinate the flowers. Herkogamy precludes spontaneous autogamy but flower closing event facilitates autogamy. In both species, the fruit is a capsule with scrotiform strophioled seeds; anemochory, ombrohydrochory and hydrochory are functional. The seeds germinate immediately if soil has moisture. Glinus species with C3 photosynthesis, facultative autogamy and polyphily are able to grow in dry and moist habitats.
\end{abstract}

Key words: Facultative autogamy, Insect pollination, Anemochory, Ombrohydrochory, Hydrochory. 


\section{Introduction}

Little is known about the pollination ecology of Molluginaceae. In this family, nectar secreting tissue is present in almost all species. In several genera, showy sepals or petals have evolved, both of which strongly suggest entomophily (Watson \& Dallwitz 1992; Kubitzki et al. 1993). There is some information on pollination ecology of $\mathrm{Mo}$ llugo L. species but not on Glinus L. genus (Robertson 1928; Pax \& Hoffmann 1934; Bogle 1970; Lin et al. 1993; Ponnuchamy et al. 2014). Hence, the present study was contemplated to provide details of pollination biology of Glinus lotoides L. and Glinus oppositifolius (L.) which usually grow in open habitats with little moisture and agricultural areas. Sastri (1956) reported that G. lotoides is widespread throughout the tropics and subtropics, especially in Africa, Asia, Australia and South Europe. Teshome \& Feyissa (2015) reported that $G$. lotoides is currently given threatened status due to its regular harvest for medicinal purpose in Ethiopia and Tanzania. Sahu et al. (2001) reported that G. oppositifolius is widely distributed in the Americas, tropical Asia, tropical Africa and Australia. The objective of the present study is to provide details of phenology and floral biology of G. lotoides and G. oppositifolius to understand their reproductive aspects.

\section{Materials and methods}

Wild patches of G. lotoides and G. oppositifolius growing in open habitats of Visakhapatnam and its surroundings in Andhra Pradesh, India $\left(17^{\circ} 42^{\prime} \mathrm{N}, 82^{\circ} 18^{\prime} \mathrm{E}\right)$ were selected for study between March 2015 and May 2017. Field trips were conducted to record phenological aspects. Ten inflorescences which were not initiated flowering on five plants were tagged and followed to record anthesis schedule and the timing of anther dehiscence. Twenty five fresh flowers were used to record the floral morphological characters such as petals, stamens, ovules and relative positions of sex organs. Nectar could not be measured and analyzed due to its secretion in minute quantity which was further depleted by thrips during mature bud and flower life. Twenty mature, but undehisced anthers, (two anthers each per flower/plant from ten plants) were collected and examined for pollen output as per the protocol described in Dafni et al. (2005). The calculation of pollen output per flower and pollen-ovule ratio was done as per the formulas described in Cruden (1977). Ten flowers each from five individuals were used to test stigma receptivity. It was tested with hydrogen peroxide from mature bud stage to flower closure/drop as per Dafni et al. (2005). Seventy inflorescences were tagged prior to the initiation of their flowering and followed for three weeks to record fruit and seed set rate in openpollinations. The fruit and seed morphological characteristics were observed in detail to evaluate their adaptations for dispersal by different means. Fields visits were made during rainy season to note the aspects of seed germination and production of new plants. Anther dehiscence schedule and stigma receptivity period, and herkogamous nature of stamens and stigmas were used to infer the sexual system. Further, how the sexual system facilitates both self- and cross-pollination was explained. Further, observations were also made to evaluate as to how these positions preclude selfpollination when flowers stay open.

Insects foraging at the flowers were observed from morning to evening on four different days for their mode of approach, landing, probing behavior and contact with the floral sexual organs. Bees and ants were identified with the representative specimens available with the Department of Environmental Sciences, Andhra University, Visakhapatnam. Butterflies were identified by consulting the books of Kunte (2007) and Gunathilagaraj et al. (1998). For each species, an area of $1 \times 1 \mathrm{~m}$ of flowering individuals of a single species consisting of approximately 450 flowers was used for foraging activity. The foraging visits of insects were recorded for $10 \mathrm{~min}$ at each hour for the entire day and the data was tabulated to record the foraging pattern and the percentage of visits made by different insect categories. The pollen/nectar collection behavior of insects was carefully observed to assess their role in effecting pollination. Ten specimens of each insect species were captured between 1400-1600 $\mathrm{h}$ and taken to the laboratory. Each specimen was washed in the drop of ethyl alcohol on a glass slide to separate pollen; then it was stained with aniline-blue and observed under microscope to count the number of pollen grains present. From this, the average number of pollen grains carried by each insect species was calculated to know the pollen carryover efficiency.

Fruit set rate was calculated by dividing the 
total number of fruits set with the total number of flowers sampled and then value obtained was expressed in percentage by multiplying it with one hundred for each flower type separately for both G. lotoides and G. opositifolius. The sample size used for 8-12-stamened flowers in G. lotoides and for 4-6-stamened flowers in G. oppositifolius was provided in Table 4. Seed set rate was calculated by dividing the total number of seeds set with the average number of ovules per flower multiplied by the total number of fruits set and then the value obtained was expressed in percentage by multiplying it with one hundred for each flower type separately for both the species.

\section{Results}

\section{The Plant}

G. lotoides and G. oppositifolius are low-growing prostrate, spreading, annual herbs which grow in open sandy soils, cultivated fields and open waste lands. In soils with enough moisture, they produce well developed tap root and survive throughout the year producing flowers and fruits simultaneously or alternately. In both the species, the stem is soft, succulent, pubescent and much-branched carpeting the soil with its foliage. In G. lotoides, the basal leaves are borne in a rosette form while the upper ones in verticillate form or rarely arranged opposite, and densely stellate tomentose. In $G$. oppositifolius, the leaves are arranged in pseudo-whorls of 3-6 or opposite to each other.

\section{Flowering}

In G. lotoides and G. oppositifolius, the flowering is profuse when soil is very damp which occurs during July-October due to monsoonal rains (Figs. 1a, 1f). In G. lotoides, the flowers are borne on $1.5 \mathrm{~mm}$ long stalks in axillary cymes and each cyme consists of $4.72 \pm 1.3$ (mean \pm SD) flowers and each plant produces $82.5 \pm 33.65$ flowers. In

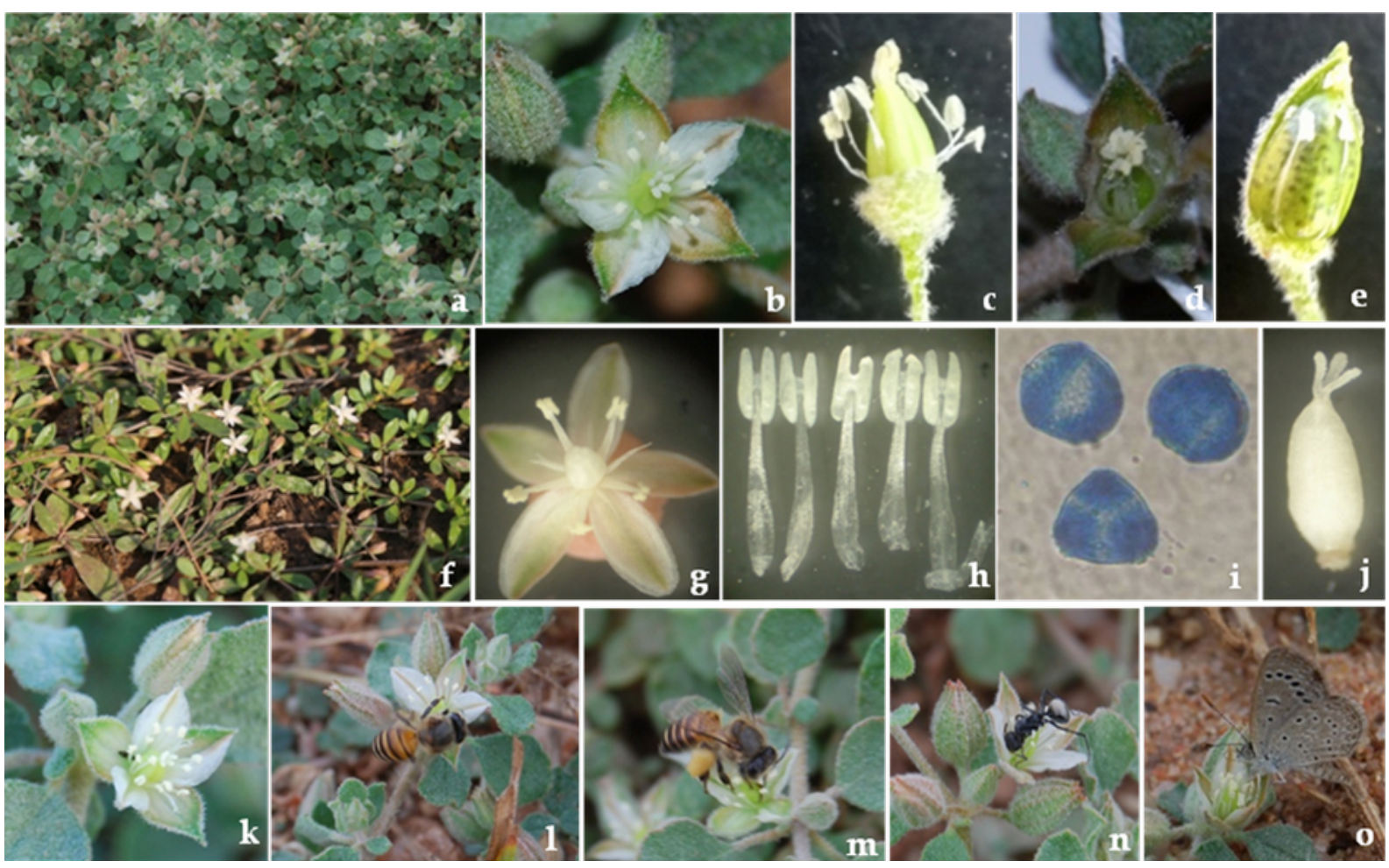

Figura 1. a-e Glinus lotoides. a. Fase de floración; b: Flor completamente abierta; c: Estambres y estigma; d: Cierre de flor a las 1800 h del día de la antesis; e: Capsula del fruro con estambres y estigma intactos tras marchitarse. f-j Glinus oppositifolius. f: Fase de floración; g: Flor; h: Estambres dehiscentes; i: Granos de polen; j: Ovario con tres estigmas. k-o Glinus lotoides: k: Haplothrips sp. alimentándose de néctar; l: Apis cerana recogiendo polen; m: Apis cerana recogiendo nectar; n: Camponotus sp. recogiendo nectar; o: Lycénido, Zizeeria karsandra, recogiendo nectar.

Figure 1. a-e Glinus lotoides. a. Flowering phase; b: Fully open flower; c: Stamens and stigma; d: Flower closure at 1800 h on the day of anthesis; e: Fruit capsule with stamens and stigma intact in withered state. f-j Glinus oppositifolius. f: Flowering phase; g: Flower; h: Dehisced stamens; i: Pollen grains; j: Ovary with three stigmas. k-o Glinus lotoides: k: Haplothrips sp. feeding on nectar; l: Apis cerana collecting pollen; m: Apis cerana collecting nectar; n: Camponotus sp. collecting nectar; o: Lycaenid butterfly, Zizeeria karsandra collecting nectar. 
G. oppositifolius, the flowers are borne on 3-7 $\mathrm{mm}$ long pedicels in axillary fascicles and each fascicle consists of $7.5 \pm 1.5$ flowers and each plant produces $64.52 \pm 41.28$ flowers.

\section{Flower morphology}

In both the species, the flowers are small, odourless, actinomorphic and bisexual (Figs. 1b, 1g). They are $6.1 \pm 1.28 \mathrm{~mm}$ long, $7.42 \pm 1.25 \mathrm{~mm}$ wide in G. lotoides and $3.51 \pm 0.5 \mathrm{~mm}$ long, 8.57 $\pm 0.7 \mathrm{~mm}$ wide in $G$. oppositifolius. In both the species, the calyx and corolla are represented by perianth with 5 or rarely 6 tepals. The tepals are succulent, free and arranged in quincuncial aestivation in both the species but they are $6.02 \pm 0.19$ $\mathrm{mm}$ long, $4.05 \pm 0.2 \mathrm{~mm}$ wide, whitish green adaxially and green abaxially, ovate-oblong and covered with stellate hairs in G. lotoides while they are $4.01 \pm 0.2 \mathrm{~mm}$ long, $2.03 \pm 0.2 \mathrm{~mm}$ wide, creamy white adaxially and brownish orange abaxially, ovate-oblong and pubescent in $G$. oppositifolius. The stamens are 8 to 12 , free, white and arranged in two whorls (Fig. 1c). The stamens of inner whorl close to ovary base are long and form a short tube at the base around the ovary while those of the outer whorl are short. In G. lotoides, the stamens of both whorls are usually anti-tepalous and occasionally alterni-tepalous. The flowers with 8 -stamens constitute $14.28 \%$, those with 9 -stamens $21.42 \%$, those with 10 -stamens $42.85 \%$, 11 -stamens $19.04 \%$ and 12-stamens $2.38 \%$. In G. oppositifolius, the stamen are 4 to 6 , free but connate at the base, and alternitepalous. The flowers with 4-stamens constitute $5 \%$, those with 5 -stamens $80 \%$ and those with 6 stamens $15 \%$. In both the species, the anthers are $\mathrm{H}$-shaped, white, dithecous and versatile (Fig. 1h). In $G$. lotoides, the staminodes are 5-7, petaloid, white, bifid and usually alterni-tepalous but occasionally in between short stamens; they extend be- yond the height of long stamens. In G. oppositifolius, the staminodes are 5 or 6 , petaloid, white, bifid and anti-tepalous. In G. lotoides, the ovary ( $5 \pm 0.23 \mathrm{~mm}$ long and $2.03 \pm 0.17 \mathrm{~mm}$ wide) is green, pentacarpellary and pentalocular syncarpous while in G. oppositifolius, the ovary $(4.07 \pm$ $0.16 \mathrm{~mm}$ long and $2 \pm 0.01 \mathrm{~mm}$ wide) is green, tri-carpellary and tri-locular syncarpous. In both the species, the ovules in each locule are arranged on axile placentation. The ovule number varied from $181.9 \pm 35.28$ to $242.4 \pm 35.14$ in 8 - and 12 stamened flowers in G. lotoides and from $115.5 \pm$ 7.1 to $137.7 \pm 9.9$ in 4- and 6-stamened flowers in G. oppositifolius (Table 1). In both the species, the ovule production trend showed that the number of ovules produced gradually increased with a gradual increase in the number of stamens per anther and pollen out per flower but the variation is not significant. The style is absent in both the species but $G$. lotoides has five greenish white stigmas while G. oppositifolius has three creamy white stigmas (Fig. 1j). In both the species, the stigmas are free, spreading, papillate, wet and shiny.

\section{Floral biology}

Mature buds open during 1400-1500 h in G. lotoides and during 1200-1400 $\mathrm{h}$ in G. oppositifolius. Individual buds open gradually over a duration of 30 to 40 minutes in G. lotoides and 10 to 15 minutes in G. oppositifolius. In both species, the anthers dehisce by longitudinal slits during anthesis. In $G$. lotoides, the pollen output per anther varied from $1,193.85 \pm 70.25$ to $1,371.85 \pm 65.76$ and from $10,974.85 \pm 526.08$ to $14,326.28 \pm$ 843.03 per flower in 8 - to 12 -stamened flowers respectively (Table 1). In G. oppositifolius, the pollen output per anther varied from 1,151 \pm 67.22 to $957.33 \pm 49.1$ and from $4,604 \pm 268.9$ to $5,744 \pm 295.1$ per flower in 4 to 6 -stamened flowers (Table 1). In both the species, the pollen pro-

\begin{tabular}{|c|c|c|c|c|c|}
\hline Flower type & $\begin{array}{l}\text { Percentage of } \\
\text { occurrence }\end{array}$ & $\begin{array}{c}\text { Mean } \pm \text { SD } \\
\text { pollen output/anther }\end{array}$ & $\begin{array}{c}\text { Mean } \pm \text { SD } \\
\text { pollen output/flower }\end{array}$ & $\begin{array}{c}\text { Mean } \pm \text { SD } \\
\text { No. ovules/flower }\end{array}$ & $\begin{array}{l}\text { Pollen: ovule } \\
\text { ratio }\end{array}$ \\
\hline \multicolumn{6}{|c|}{ Glinus lotoides } \\
\hline 8-stamened & 14.20 & $1371.85 \pm 65.76$ & $10974.85 \pm 526.08$ & $181.9 \pm 35.28$ & $60: 1$ \\
\hline 9-stamened & 21.42 & $1331.85 \pm 91.46$ & $11986.71 \pm 823.21$ & $196.7 \pm 35.78$ & 61:1 \\
\hline 10-stamened & 42.85 & $1304.57 \pm 62.65$ & $13045.71 \pm 626.57$ & $221.8 \pm 40.67$ & $59: 1$ \\
\hline 11-stamened & 19.04 & $1221.85 \pm 61.36$ & $13440.42 \pm 674.99$ & $230.2 \pm 34.23$ & $58: 1$ \\
\hline 12-stamened & 2.38 & $1193.85 \pm 70.25$ & $14326.28 \pm 843.03$ & $242.4 \pm 35.14$ & $59: 1$ \\
\hline \multicolumn{6}{|c|}{ Glinus oppositifolius } \\
\hline 4-stamened & 5 & $1151 \pm 67.2$ & $4604 \pm 268.9$ & $115.5 \pm 7.1$ & $40: 1$ \\
\hline 5-stamened & 80 & $1027 \pm 55.5$ & $5133 \pm 277.5$ & $128.6 \pm 7.7$ & $40: 1$ \\
\hline 6-stamened & 15 & $957 \pm 49.1$ & $5744 \pm 295.1$ & $137.7 \pm 9.9$ & 41.9: 1 \\
\hline
\end{tabular}

Tabla 1. Aspectos del polen y óvulos de Glinus lotoides y Glinus oppositifolius

Table 1. Pollen and ovule aspects in Glinus lotoides and Glinus oppositifolius. 
duction trend showed that the pollen output rate gradually increased with a gradual decrease in the number of stamens produced per flower. In $G$. lotoides, the pollen-ovule ratio varied from 58: 1 to 61:1 in 8- to 12-stamened flowers respectively. In G. oppositifolius, the pollen-ovule ratio is $40: 1$ and it is constant despite variation in the number of stamens and ovules. In both the species, the pollen grains are white, spheroidal, tricolporate, tri-zonoaperturate, colpal membrane densely granulated, and tectum with scabrate ornamentation (Fig. 1i) but the grain size is $32.52 \pm 4.28 \mu \mathrm{m}$ in G. lotoides and $29.34 \pm 4.26 \mu \mathrm{m}$ in G. oppositifolius. In both the species, the stigma is receptive from anthesis onwards and remains receptive until the noon of the following day. Further, the nectar is secreted in traces during mature bud stage. The tepals together with the staminodes, stamens and stigma close back completely by $1800 \mathrm{~h}$ on the same day (Fig. 1d) and remain in place in fertilized flowers until fruit dispersal. But, the un-fertilized flowers fall off after 7-10 days in $G$. lotoides and after 6-8 days in G. oppositifolius.

In $G$. lotoides, the fully open flowers show different positions of the stamens and the stigmas. The stigmas are situated beyond the height of short stamens but below the height of long stamens. In G. oppositifolius, the stamens, staminodes and stigmas are situated at the same height. But, in both the species, the sex organs are spatially separated and precludes spontaneous autogamy during open state of the flower. However, during the closure of the flower, the closely spaced dehisced anthers of long stamens contact the stigmas facilitating spontaneous autogamy but its occurrence is dependent on the availability of pollen in the anthers.

\section{Foraging activity of insects}

In G. lotoides and G. oppositifolius, thrips species, Haplothrips sp. (Amyot \& Serville, 1843) (Thysanoptera: Thripidae) ovi-posited during early stage of floral bud (Fig. 1k). The larvae emerged from the eggs in synchrony with anthesis and nectar production in flowers. The larvae and adults foraged for pollen and nectar. Individual thrips were dusted with pollen during their movements within the flowers and carried 428 to 635 pollen grains of $G$. lotoides and 157 to 253 pollen grains of $G$. oppositifolius on their body setae, wings and legs. In both the species, the flowers were foraged between 1300/1400-1700 h with

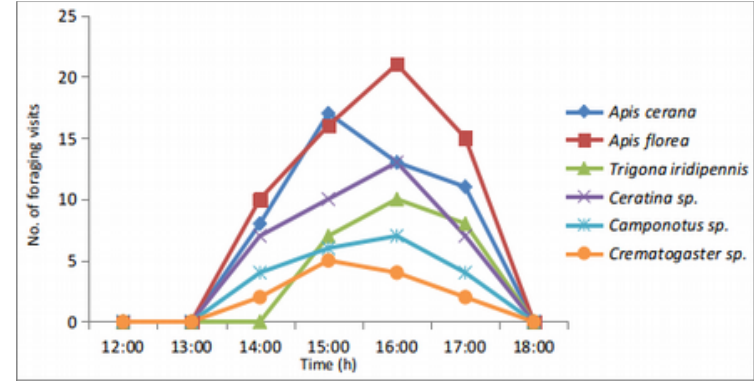

Figura 3. Actividad horaria de recolección de abejas y hormigas en Glinus lotoides.

Figure 3. Hourly foraging activity of bees and ants on Glinus lotoides.

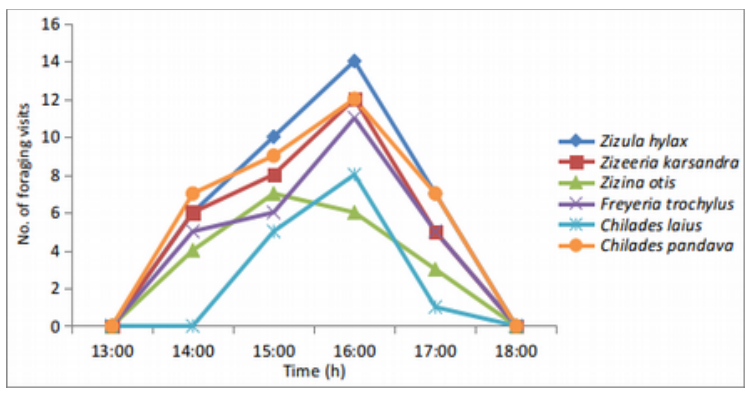

Figura 4. Actividad horaria de recolección de licénidos en Glinus lotoides.

Figure 4. Hourly foraging activity of lycaenid butterflies on $G$. lotoides.

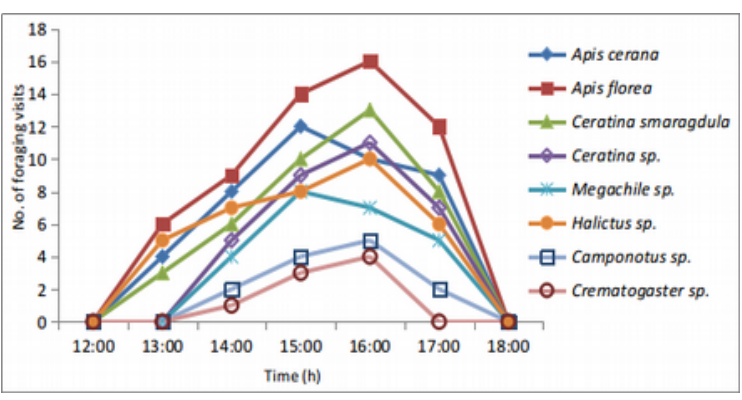

Figura 5. Actividad horaria de recolección de abejas y hormigas en Glinus oppositifolius.

Figure 5. Hourly foraging activity of bees and ants on $G$. oppositifolius.

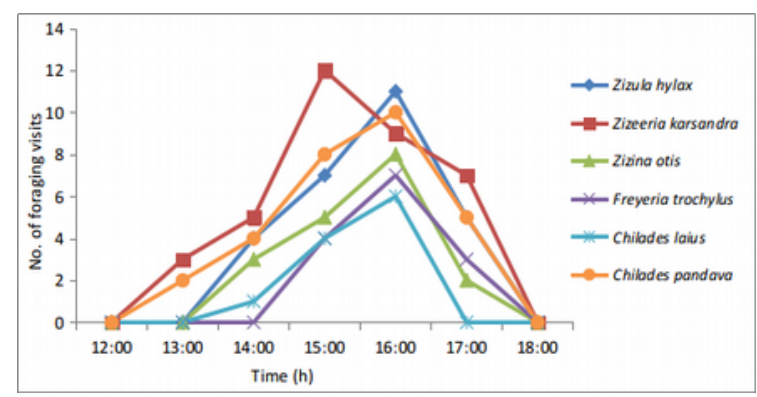

Figura 6. Actividad horaria de recolección de licénidos en Glinus oppositifolius.

Figure 6. Hourly foraging activity of lycaenid butterflies on $G$. oppositifolius. 
concentrated foraging activity between 1500-1600 h (Figs. 2-5). The foragers included bees which visited for pollen and nectar, ants and butterflies which visited for only nectar.

On G. lotoides, the bee foragers were Apis cerana (Fabricius, 1793) (Figs. 11, 1m), Apis florea (Fabricius, 1793), Trigona iridipennis (Smith, 1854) and Ceratina sp. (Latreille, 1802). The ant foragers included Camponotus sp. (Mayr, 1861) (Fig. 1n) and Crematogaster sp. (Lund, 1831). The butterfly foragers included only lycaenids, namely, Zizula hylax (Fabricius, 1775), Zizeeria karsandra (Moore, 1865) (Fig. 10), Zizina otis (Fabricius, 1787), Freyeria trochylus (Forster, 1980), Chilades laius (Stoll, 1780) and Chilades pandava (Horsefield, 1829) (Table 2). On G. oppositifolius, the bee foragers were A. cerana, $A$. florea (Figs. 6a, 6b), Ceratina sp. (Figs. 6c, 6d), Ceratina smaragdula (Bingham 1897) (Fig. 6e), Halictus sp. (Cockerell, 1897) and Megachile sp. (Latrieille, 1802) (Fig. 6f). The ant foragers included Camponotus sp. and Crematogaster sp. The butterfly foragers included only lycaenids, namely, Z. hylax (Fig. 6g), Z. karsandra (Figs. 6h, 6i), Z. otis (Fig. 6j), F. trochylus, C. laius and $C$. pandava (Table 2). In both the species, these insects approached the flowers in upright position, landed on the tepals and then probed for forage collection. Bees first accessed anthers to collect pollen and then moved to the flower base to collect nectar, if available in the same and/or differ- ent visits. Ants were resident foragers and continuously crawled all over the plant and accessed the floral base to collect nectar. Butterflies stretched out their proboscis and inserted into the flower base to collect nectar. All insect species collected forage from several flowers of different cymes of the same or different plants to collect the forage. The bees during pollen collection brushed against the stigmas with their ventral surface effecting sternotribic pollination. Further, the bees and also ants during nectar collection brushed against anthers and stigmas with their dorsal surface effecting nototribic pollination. The butterflies during nectar collection contacted the stamens and stigmas with their proboscis and front side of head and ventral surface of thorax and abdomen effecting sternotribic pollination. Their wings never contacted the stamens and stigma during nectar collection as they kept them in vertical position. On $G$. lotoides flowers, bees made $47 \%$, ants $9 \%$ and lycaenids $44 \%$ of total foraging visits. On $G$. oppositifolius flowers, bees made $60 \%$, ants $5 \%$ and lycaenids $35 \%$ of total foraging visits. The body washings of insects collected from the flowers of both G. lotoides and G. oppositifolius during peak foraging period revealed that all insects carry pollen but bees carry the highest number of pollen grains. Further, the mean number of pollen grains varied with each insect species (Table 3). The nectar secretion in traces and its depletion by thrips during and after anthesis in both the plant

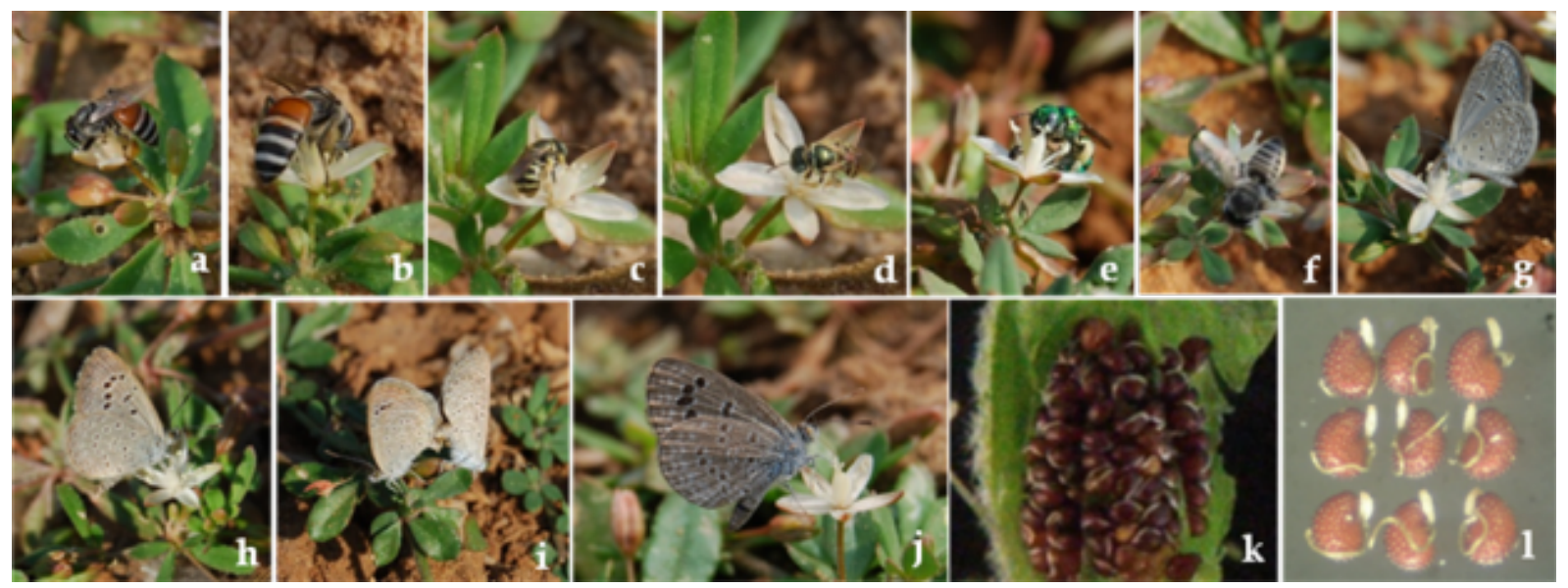

Figure 6. a-f. Glinus oppositifolius. a: Apis florea recogiendo polen; b: Apis florea recogiendo néctar; c: Ceratina sp. recogiendo polen; d: Ceratina sp. recogiendo néctar; e: Ceratina smaragdula recogiendo néctar; f: Megachile sp. recogiendo néctar; g-j Licénidos. g: Zizula hylax; h: Zizeeria karsandra; i: Zizeeria karsandra enestado de cópula; j: Zizina otis; k: Semillas de Glinus lotoides; l: Semillas de Glinus oppositifolius.

Figure 6. a-f. Glinus oppositifolius. a: Apis florea collecting pollen; b: Apis florea collecting nectar; c: Ceratina sp. collecting pollen; d: Ceratina sp. collecting nectar; e: Ceratina smaragdula collecting nectar; f: Megachile sp. collecting nectar; g-j Lycaenid butterflies. g: Zizula hylax; h: Zizeeria karsandra; i: Zizeeria karsandra in mating state; j: Zizina otis; k: Glinus lotoides seeds; l: Glinus oppositifolius seeds. 


\begin{tabular}{|c|c|c|c|c|}
\hline Order/Family & Insect species & Glinus lotoides & Glinus oppositifolius & Forage sought \\
\hline \multicolumn{5}{|l|}{ Hymenoptera } \\
\hline \multirow[t]{5}{*}{ Apidae } & Apis cerana $\mathrm{F}$. & + & + & Pollen + Nectar \\
\hline & Apis florea $\mathrm{F}$. & + & + & Pollen + Nectar \\
\hline & Trigona iridipennis Smith & + & - & Pollen + Nectar \\
\hline & Ceratina smaragdula F. & - & + & Pollen + Nectar \\
\hline & Ceratina sp. & + & + & Pollen + Nectar \\
\hline Halictidae & Halictus sp. & - & + & Pollen + Nectar \\
\hline Megachilidae & Megachile sp. & - & + & Pollen + Nectar \\
\hline \multirow[t]{2}{*}{ Formicidae } & Camponotus sp. & + & + & Nectar \\
\hline & Crematogaster sp. & + & + & Nectar \\
\hline \multicolumn{5}{|l|}{ Thysanoptera } \\
\hline Thripidae & Haplothrips sp. & + & + & Pollen + Nectar \\
\hline \multicolumn{5}{|l|}{ Lepidoptera } \\
\hline \multirow[t]{6}{*}{ Lycaenidae } & Zizula hylax F. & + & + & Nectar \\
\hline & Zizeeria karsandra Moore & + & + & Nectar \\
\hline & Zizina otis $\mathrm{F}$. & + & + & Nectar \\
\hline & Freyeria trochylus Freyer & + & + & Nectar \\
\hline & Chilades laius Stoll & + & + & Nectar \\
\hline & Chilades pandava Horsfield & + & + & Nectar \\
\hline
\end{tabular}

Tabla 2. Lista de insectos polinizadores de Glinus lotoides y Glinus oppositifolius.

Table 2. List of insect pollinators on Glinus lotoides and Glinus oppositifolius.

\begin{tabular}{lccccccc}
\hline Insect species & Sample size (N) & \multicolumn{3}{c}{ Glinus lotoides } & \multicolumn{3}{c}{ Glinus oppositifolius } \\
\cline { 3 - 7 } & & Number of pollen grains & Number of pollen grains \\
\cline { 3 - 7 } & 10 & Range & Mean & S.D. & Range & Mean & S.D. \\
\hline Apis cerana & 10 & $78-252$ & 167.1 & 56.83 & $66-214$ & 140.5 & 42.9 \\
Apis florea & 10 & $43-214$ & 129.2 & 46.26 & - & -- & - \\
Trigona iridipennis & 10 & -- & -- & -- & $68-164$ & 115.9 & 24.8 \\
Ceratina smaragdula & 10 & $35-94$ & 64.1 & 17.44 & $41-117$ & 84.2 & 21.6 \\
Ceratina sp. & 10 & -- & -- & -- & $27-63$ & 44.1 & 9.1 \\
Halictus sp. & & -- & -- & -- & $43-102$ & 74.8 & 16.1 \\
Megachile sp. & 10 & $27-58$ & 39.4 & 8.59 & $22-45$ & 31.3 & 7.4 \\
Camponotus sp. & 10 & $23-46$ & 34.5 & 6.43 & $13-34$ & 25.1 & 6.4 \\
Crematogaster sp. & 10 & $8-31$ & 21.4 & 6.29 & $11-38$ & 26.8 & 7.2 \\
Zizula hylax & 10 & $15-40$ & 27.8 & 7.40 & $9-46$ & 28.8 & 9.2 \\
Zizeeria karsandra & 10 & $11-29$ & 20.8 & 5.24 & $14-30$ & 23.1 & 5.1 \\
Zizina otis & 10 & $10-38$ & 25.4 & 7.4 & $7-29$ & 19.3 & 6.1 \\
Freyeria trochylus & 10 & $12-34$ & 23.3 & 6.37 & $10-35$ & 24.8 & 7.0 \\
Chilades laius & 10 & $10-42$ & 28.4 & 8.27 & $12-41$ & 28.1 & 7.2 \\
Chilades pandava & & &
\end{tabular}

Tabla 3. Polen registrado en lavados de cuerpo de insectos obtenidos en Glinus lotoides y Glinus oppositifolius.

Table 3. Pollen recorded in the body washings of insects on Glinus lotoides and Glinus oppositifolius.

species appeared to be driving the insects to visit as many flowering cymes as possible to quench their thirst for nectar. Such a foraging behavior was considered to be facilitating the promotion of cross-pollination.

\section{Fruiting ecology and seed dispersal}

The pollinated and fertilized flowers grow continually and produce fruits within 8-12 days in G. lotoides and 7-10 days in G. oppositifolius. In both the species, the stamens and stigmas are persistent and remain inside due to the closure of the flower (Fig. 1e). The tepals bulge gradually and protect the bulging ovary in which the seeds form and mature. In G. lotoides, natural fruit set rate varied from $88 \%$ to $92 \%$ while seed set rate varied from
$85 \%$ to $93 \%$ in 8 - to 12 -stamened flowers respectively (Table 4). In G. oppositifolius, natural fruit set rate varied from $88 \%$ to $92 \%$ while seed set rate varied from $88 \%$ to $91 \%$ in 4 - to 6 -stamened flowers respectively (Table 4). Fruit is a loculicidal 5 -valved capsule, $6.05 \pm 0.75 \mathrm{~mm}$ long and $4.1 \pm 0.64 \mathrm{~mm}$ wide in G. lotoides while it is an ellipsoid loculicidal 3 -valved capsule, $5.5 \pm 0.5$ $\mathrm{mm}$ long and $2.1 \pm 0.2 \mathrm{~mm}$ wide in G. oppositifolius. In both the species, the fruit is stalked, membranous and densely pubescent. In G. lotoides, the seeds are small, reniform, smooth, 0.7 $\mathrm{mm}$ long and $0.5 \mathrm{~mm}$ wide, initially red and finally dark brown and have a white aril of funicular origin developed into elongate filiform strophiole (Fig. 6k). In G. oppositifolius, the seeds are 


\begin{tabular}{lcccc}
\hline Flower type & Number of flowers sampled & Number of flowers set fruit & Fruit set (\%) & Seed set (\%) \\
\hline Glinus lotoides & & & & \\
8-stamened & 50 & 45 & 90 & 85 \\
9-stamened & 60 & 53 & 88 & 87 \\
10-stamened & 110 & 98 & 89 & 90 \\
11-stamened & 45 & 41 & 91 & 92 \\
12-stamened & 25 & 23 & 92 & 93 \\
Glinus oppositifolius & & & & 88 \\
4-stamened & 61 & 54 & 91 & 88 \\
5-stamened & 225 & 206 & 92 & 90 \\
6-stamened & 105 & 97 & 91 & 91 \\
\hline
\end{tabular}

Tabla 4. Proporción entre los conjuntos de frutos y semillas de Glinus lotoides y Glinus oppositifolius.

Table 4. Natural fruit and seed set rate in Glinus lotoides and Glinus oppositifolius.

small, sub-reniform, granulose, $0.9 \mathrm{~mm}$ long and $0.7 \mathrm{~mm}$ wide, reddish-brown and have a white aril of funicular origin developed into extensively curved scrotiform strophiole (Fig. 61). In both the plant species, the seeds are arranged in two rows in each locule. Dry capsules of both the species break open when tepals are wet and expose the seeds. But the seeds remain so and gradually separate and fall to the ground on their own on clear sunny days. In dry season, when the capsules are ripe, the plants die, dry out and become brittle. In this state, the base of the stem breaks off and it is more so when high winds prevail. Then, the plant parts roll readily and fruit and seeds disperse to other areas. On rainy days, drops of water falling on the distal opening after the locules are filled with rain water result in an explosive expulsion of water droplets and seeds. Further, water also disperses seeds fallen on the soil during rainy season. Therefore, seed dispersal is characteristically anemochorous, ombrohydrochorous and hydrochorous in both G. lotoides and G. oppositifolius.

\section{Discussion}

G. lotoides and G. oppositifolius are prostrate, spreading, annual herbs that carpet the ground in open sandy soils and agricultural lands. They occur throughout the year and show vegetative, flowering and fruiting phases in different areas. But, their robust growth, profuse flowering and fruiting is confined to wet season. The flowers borne in axillary cymes in G. lotoides and axillary fascicles in G. oppositifolius stand erect above the foliage and display their prominence. In both the species, the stems produce many branches and each branch produces several cymes or fascicles. Since the plants usually grow as green carpets, the simultaneous display of several flowers from individual plants and from the entire population(s) could enhance their attraction to insect pollinators.
Ronse De Craene (2010) stated that Glinus species have five sepals in quincuncial aestivation. In the present study, G. lotoides and G. oppositifolius have been found to have five tepals as common and six tepals as rare. The study also indicates that the word "tepal" is the appropriate word since it acts as petal adaxially and sepal abaxially. This is further substantiated by two different colours displayed on adaxial and abaxial surface. The tepals are whitish green on adaxial surface and green abaxial surface in G. lotoides and creamy white on adaxial surface and brownish orange on abaxial surface in G. oppositifolius.

In Glinus species, the stamen number is unstable and varies from five to several series which include outer staminodes also (Hoffman 1994). The staminodes are petaloid, represent the stamens that lost their function as producers of fertile pollen and antisepalous replacing a fertile stamen or alternisepalous as an appendage of upper stamen (Weberling 1989; Brockington et al. 2013). Ronse De Craene (2010) reported that in $G$. lotoides the alternisepalous whorl is complete with staminodes and odd stamen is opposite to petals. Sharma (1963) mentioned that G. lotoides flowers produce rarely more than five stamens while G. oppositifolius produce 10-13 stamens in three whorls. He also suggested a tendency for reduction with the loss of the outer stamen whorl in androecium. In the present study, G. lotoides flowers had 8-12 antitepalous functional stamens in two whorls and 5-7 alternitepalous staminodes in outer whorl. G. oppositifolius flowers had 4-6 alternitepalous functional stamens in one whorl and 5-6 antitepalous staminodes in outer whorl. In both the species, the staminodes are petaloids indicating the fusion of two adjacent stamens that lost the function of producing viable pollen in course of the evolution of flowers. These staminodes are integral features of floral morphology and appear to have evolved to serve as attractants 
to pollinators, reduce self-pollination rate and optimize the available nutrients for enhanced reproductive output in water and nutrient deficient habitats. Further, the production of staminodes appears to be an adaptation to reduce pollen production per flower, increase efficiency of pollen dispersal by limiting pollen removal by individual pollinators and enable precise contact between pollinators and pollen presenters or pollinators and stigmas. Therefore, the petaloid staminodes are evolved to perform different roles in the flowers and are unique for Glinus within Molluginaceae (Stebbins 1974; Ronse De Craene \& Smets 1993, 1995; Ronse De Craene 2013).

Hammer (1995) reported that different populations of Aizoaceae growing in the same habitat exhibit synchrony in flowering time. The period of flowering is usually short and the flowers show repeated opening but this phenomenon is restricted to a certain period of the day. Groen \& Van Der Maesen (1999) observed that the mixed populations of Aizoaceae genera, Bergeranthus Schwantes, Faucaria Schwantes and Orthopterum L. Bolus flower simultaneously. These authors suggested that such a synchrony in flowering in these genera in the same habitat collectively enable them to enhance their floral attraction to pollinators. In the present study, it is found that Glinus species form mixed and distinct populations in the same and different habitats depending on soil moisture and nutrient conditions. These species exhibit synchrony in flowering by opening flowers in the afternoon. Further, the flowers are too small, lack corolla, tepals not vividly coloured and stay open for a brief period, for three hours in $G$. lotoides and four hours in $G$. oppositifolius for visitation by insects. Therefore, the synchrony in anthesis schedule and massive floral display appear to be imperative for them to attract pollinators during the brief period of open state of flowers.

Peter et al. (2004) reported that the temperature and relative humidity are probably important cues determining flower opening in the afternoon. The specific timing of anthesis in the late afternoon is a likely mechanism to filter out generalist pollinators most active at midday, rather targeting specific group of insects, primarily bees, still active in the late afternoon. The present study indicates that afternoon anthesis in Glinus species is probably evolved in course of time to avoid competition for pollinators in a pollinator- deprived environment, especially in habitats where other herbaceous plant species flower simultaneously, show anthesis during forenoon period and attract insect pollinators with their vivid floral colors. Glinus species provide sufficient forage for insect pollinators in the afternoon period and accordingly bees, ants and lycaenid butterflies collect forage and pollinate flowers. Since bees and butterflies are active throughout day, they soon switch to fresh forage available in the habitat. Glinus species with afternoon anthesis readily provide forage, and bees and butterflies begin to shift to these floral sources and concentrate on forage collection from them. Therefore, afternoon anthesis in Glinus species could ensure insect pollination and reciprocate the insect pollinators with pollen and/or nectar.

Watson \& Dallwitz (1992) stated that Molluginaceae members are entomophilous. These authors considered nectar secreting tissue and showy tepals in several species as adaptations for entomophily. In Glinus species, the floral characters such as the erect position of flowers above foliage, adaxial surface of the tepals, petaloid staminodes and nectar secreting tissue between the ovary base, connate part of staminal filaments and scabrate ornamentation of pollen grains appear to be adaptations for insect pollination. The bees while collecting pollen and butterflies while collecting nectar effect sternotribic pollination. Further, the bees and ants while collecting nectar effect nototribic pollination. In both $G$. lotoides and G. oppositifolius, the pollen output per anther varies with the number of functional stamens present in the flowers; it increases with a decrease in the stamen number. The pollen output per flower in G. lotoides is more than double the amount produced per flower in G. oppositifolius. The variation in pollen production in these plant species is partly attributable to the number of stamens produced. The varied amount of pollen output in the flowers of the same and different inflorescences on the same plant drives the pollen collecting bees to visit the flowers across population (s) in search of more pollen collection and such a foraging activity contributes to both self- and cross-pollination. The nectar secreted in traces in both the species and nectar removal by thrips species, Haplothrips also drives the nectar collecting bees, ants and lycaenid butterflies to visit flowers across population(s) due to which both self- and cross-pollinations occur. Glinus species 
appear to be important sources of pollen for bees, especially for honey bees. Saad-Aldeen (2014) also noted that $G$. lotoides is an important pollen source for honey bees in Radom area, South Darfur State, Sudan. Further, these plant species in the study area are important nectar sources for ants and lycaenid butterflies. Among butterflies, lycaenids are the smallest, low-flying and appropriate pollinators for prostrate herbs such as Glinus species.

In both Glinus species, the flowers are protandrous because there is a brief gap between anther dehiscence and commencement of stigma receptivity. Since both male and female sexes mature almost at the same time, the flowers in these plant species can be stated as homogamous. Further, the stamens and stigmas are spatially separated in both the species; such a situation suggests that the flowers are also herkogamous. Herkogamy does not facilitate the occurrence of spontaneous autogamy despite the flowers being homogamous. However, the thrips emerging from the floral buds during anthesis and their movements in the flowers after anthesis for pollen and nectar collection could result in autogamy. They also bring about geitonogamy due to their migration to different inflorescences on the same plant for forage collection and xenogamy due to their migration to other conspecific plants for forage collection. Further, the movement of tepals together with stamens towards the pistil during flower closure facilitates contact between the sex organs and effects spontaneous autogamy if pollen is still available in the dehisced stamens. Further, the tiny thrips by moving into the closed flowers from apical portion and from sides may effect geitonogamy or xenogamy. Therefore, G. lotoides and G. oppositifolius while keeping the options open for spontaneous or vector-mediated selfing exhibit polyphily involving bees, ants, butterflies and thrips as pollinators.

In the present study, Glinus species show variation in the number of carpels and ovules per flower. The flowers of $G$. lotoides produce five carpels while those of $G$. oppositifolius produce three carpels. Likewise, the number of ovules also varies depending on the number of stamens and pollen output per flower; the ovules are relatively more in $G$. lotoides than in G. oppositifolius. This ovule production trend indicates that the pollen output increases with an increase in ovule number in order to provide sufficient pollen to fertilize as many ovules as possible through spontaneous autogamy or vector-mediated pollination. This situation is reflected in the natural fruit and seed set rates in both plant species. The highest fruit and seed set rates and the lowest pollen-ovule ratios recorded in $G$. lotoides and G. oppositifolius indicate that they are facultatively autogamous but breeding test is required for confirmation.

Bittrich (1990) reported that Molluginaceae members produce capsules with many seeds and the capsules dehisce loculicidally to expose seeds. In $G$. lotoides, the capsules open when moistened with the aid of expanding keels. In the present study, in G. lotoides and G. oppositifolius, the fertilized flowers produce fruits within a week or two. The fruit is a capsule but it is 5-valved in $G$. lotoides and 3-valved in G. oppositifolius. In dry season, plants with ripe and dry capsules break off which are then dispersed by wind. Dry capsules break open loculicidally when tepals become wet and then expose the seeds. However, the seeds remain attached to the base of the perianth. In both the species, the seeds exposed from the capsules fall to the ground on clear sunny days. On rainy days, water drops find their way into the fruit through the distal opening and the fruit filled with water expels both water and seeds explosively. Further, seeds fallen on the ground disperse through surface water runoff during rain fall. Therefore, $G$. lotoides and $G$. oppositifolius exhibit anemochory, ombrohydrochory and hydrochory.

Glinus species produce seeds with a white aril of funicular origin and the latter develops into elongate, filiform strophiole (Narayana 1962; Hofmann 1973). Glinus genus is characterized by its seeds with a filiform appendaged aril and indumentum of often stellate hairs (Ronse De Craene 2013). In this study, G. lotoides has been found to produce small reniform, smooth and dark brown seeds and its seeds have a white aril of funicular origin developed into elongate filiform strophiole. In $G$. oppositifolius, the seeds are small, sub-reniform and reddish-brown with a white aril of funicular origin formed into extensively curved scrotiform strophiole. The presence of filiform or scrotiform strophiole in Glinus species appears to be an adaptation for seed dispersal by ants (Costea et al. 2003). But, ants have not been found to use the strophiole as food and carry seeds of these species. However, further studies if taken up on this aspect may throw more light either to confirm 
or refute this observation.

Balcha (2009) reported that $G$. lotoides has short seed viability period. Teshome \& Feyissa (2015) also reported that this species propagates by seed but short period of seed viability and poor seed germination percentage are the limiting factors for its invasiveness. The present study showed that both $G$. lotoides and G. oppositifolius produce several batches of populations in a year and their seeds germinate as soon as they are dispersed but their germination could be related to soil moisture which plays an important role in breaking the seed coat. Therefore, Glinus species appear to have short period of seed viability as reported by Balcha (2009) and Teshome \& Feyissa (2015) and also the viability may also be attributable to the extent of genetic variation achieved through vector-mediated pollination.

Rama Das \& Raghavendra (1973) noted that $G$. lotoides and $G$. oppositifolius are C3 species. Glinus with C3 photosynthesis have developed different pollination mechanisms to maximize fruit and seed set rate. Genetic variation achieved through insect pollination would enable to extend their distribution range by producing populations especially in dry and moist habitats. Since Glinus species grow well in these habitats and carpet the soil, they can be considered as important candidate species in soil erosion control and in ecorestoration programs.

\section{References}

Balcha A. 2009. Studies on propagation biology of four and phenology of one medicinal plants. Addis Ababa, Ethiopia: Addis Ababa University. Ph.D. Thesis.

Bittrich V. 1990. Systematic studies in Aizoaceae. Mitteilungen aus dem Institut fur Allgemeine Botanik Hamburg 23b: 491-507.

Bogle AL. 1970. The genera of Molluginaceae and Aizoaceae in the southeastern United States. Journal of the Arnold Arboretum 51: 431-462.

Brockington S, Santos PD, Glover B and Craene LPR. 2013. Androecial evolution in Caryophyllales in light of a paraphyletic Molluginaceae. American Journal of Botany 100: 1757-1778.

Costea M, Weaver SE and Tardif FJ. 2003. The biology of Canadian weeds. 130. Amaranthus retroflexus L., A. powellii S. Watson and A. hybridus L. Canadian Journal of Plant Science 84: 631-668.

Cruden RW. 1977. Pollen-ovule ratios: a conservative indicator of breeding systems in flowering plants. Evolution 31: 32-46.

Dafni A, Kevan PG \& Husband BC. 2005. Practical Polli- nation Biology. Cambridge, UK: Enviroquest Ltd.

Groen LE \& Van Der Maesen LJG. 1999. Revision of the genus Faucaria (Ruschioideae: Aizoaceae) in South Africa. Bothalia 29: 35-58.

Gunathilagaraj K, Perumal TNA, Jayaram K \& Ganesh Kumar M. 1998. Field Guide: Some South Indian Butterflies. Niligiri Wildlife and Environmental Association, Niligiri.

Hammer S. 1995. Mastering the art of growing mesembs. Cactus and Succulent J. (U.S.) 67: 195-247.

Hofmann U. 1973. Morphologische Untersuchungen zur Umgrenzung und Gliederung der Aizoaceen. Botanische Jahrbucher fur Systematik, Pflanzengeschichte und Pflanzengeographie 93: 247-324.

Hofmann U. 1994. Flower morphology and ontogeny. In: Caryophyllales: Evolution and Systematics (Behnke HD, Mabry TJ eds.). Berlin: Springer, pp. 123-166.

Kubitzki K, Rohwer JG \& Bittrich V. 1993. The families and genera of vascular plants. II. Flowering plants. Dicotyledons. Magnoliid, Hamamelid and CaryophiIlid families. Berlin: Springer-Verlag.

Kunte K. 2007. India - A Lifescape: Butterflies of Peninsular India. Hyderabad, India: Universities Press.

Lin SH, Chang SY \& Chen SH. 1993. The study of beecollected pollen loads in Nantou, Taiwan. Taiwania 38: 117-133.

Narayana HS. 1962. Seed structure in the Aizoaceae. In: Proceedings of the Summer School of Botany (Maheshwari P, Johri BM \& Vasil LK eds.), New Delhi: Ministry of Scientific Research and Cultural Affairs, pp. 220-230.

Pax F \& Hoffmann K. 1934. Caryophyllaceae. In: Die naturlichen Pflanzenfamilien. 2. Aufl. Vol. 16c. (Engler A \& Prantl K eds.). Leipzig, Germany: W. Engelmann, pp. 275-364.

Peter Cl, Dold AP, Barker NP \& Ripley BS. 2004. Pollination biology of Bergeranthus multiceps (Aizoaceae) with preliminary observations of repeated flower opening and closure. South African Journal of Science 100: 624-629.

Ponnuchamy R, Bonhomme V, Prasad S, Das L, Patel P \& Gaucherel C. 2014. Honey pollen: using melissopalynology to understand foraging preferences of bees in tropical South India. PLoS ONE 9: e101618 [11].

Rama Das VS \& Raghavendra AS. 1973. A screening of the dicotyledonous weed flora for the occurrence of C4 dicarboxylic acid pathway of photosynthesis. Proceedings of the Indian Academy of Science, Section B. 77 : 93-100.

Robertson C. 1928. Flowers and Insects. XXV. Ecology 9: 505-526.

Ronse De Craene LP. 2010. Floral diagrams: an aid to understanding flower morphology and evolution. New York: Cambridge Press.

Ronse De Craene LP. 2013. Reevaluation of the perianth and androecium in Caryophyllales: implications for flower evolution. Plant Systematics and Evolution 299: 1599-1636.

Ronse De Craene LP \& Smets EF. 1993. The distribution and systematic relevance of the androecial character polymery. Botanical Journal of the Linnean 
Society 113: $285-350$.

Ronse De Craene LP \& Smets FF. 1995. The distribution and systematic relegance of the androecial character oligomery. Botanical Journal of the Linnean Society 118: 193-247.

Saad-Aldeen IMAG. 2014. Survey of some major pollen sources for bees in Radom area South Darfur State. Shambat, Sudan: Sudan University of Science and Technology. M.Sc. Dissertation.

Sahu NP, Koike K \& Banerjee S. 2001. Triterpenoid saponins from Mollugo spergula. Phytochem. 58: 1177-1182.

Sastri BN. 1956. The Wealth of India, Raw Materials. Vol. IV (F-G). New Delhi: CSIR.

Sharma HP. 1963. Studies in the order Centrospermales II. Vascular anatomy of the flower of certain species of the Molluginaceae. The Indian Botanical Society 42: 19-32.
Stebbins GL. 1974. Flowering plants: evolution above the species level. Cambridge, USA: Belknap, Harvard University.

Stebbins GL. 1989. Introduction: Herbert Baker: A renaissance botanist. In: The Evolutionary Ecology of Plants (Bock JH \& Linhart YB eds.)- San Franscisco: Westview Press, pp. 1-4.

Teshome S \& Feyissa T. 2015. In vitro callus induction and shoot regeneration from leaf explants of Glinus lotoides (L.)- An important medicinal plant. American Journal of Plant Sciences 6: 1329-1340.

Watson L \& Dallwitz MJ. 1992. The families of flowering plants: descriptions, illustrations, identification, and information retrieval, ver. 2018. Available at https://www.delta-intkey.com/angio/index.htm (accessed on January 2018).

Weberling F. 1989. Morphology of flowers and inflorescences. London: Cambridge University Press. 